\title{
ÚJ RÖVID LÉPÉSES BELSŐPONTOS ALGORITMUS HORIZONTÁLIS LINEÁRIS KOMPLEMENTARITÁSI FELADATOKRA
}

\section{NEW SHORT-STEP INTERIOR-POINT ALGORITHM FOR HORIZONTAL LINEAR COMPLEMENTARITY PROBLEMS}

\author{
Darvay Zsolt ${ }^{1}$, Takács Petra-Renáta ${ }^{1}$ \\ ${ }^{I}$ Babeş-Bolyai Tudományegyetem, Matematika és Informatika Kar, Magyar Mate- \\ matika és Informatika Intézet, Cím: 400084, Románia, Kolozsvár, Kogălniceanu 1; \\ Telefon: +40 264 405327, darvay@cs.ubbcluj.ro
}

\begin{abstract}
Several algorithms related to linear and convex quadratic optimization problems can be used for solving different kinds of engeneering problems. The existence and determination of the optimum can be analysed in a more general frame, which can be defined as a linear complementarity problem. In this paper we introduce an interior-point method for solving horizontal linear complementarity problems, which is based on a new search direction. In this way, the interior-point methods related to more general classes of problems can be handled uniformly.
\end{abstract}

Keywords: interior-point algorithm, short-step method, horizontal linear complementarity problem, search direction, Newton's method.

\section{Összefoglalás}

Egyes lineáris és konvex kvadratikus optimalizálási feladatokra vonatkozó algoritmusok különböző mérnöki jellegü problémák megoldására alkalmazhatóak. Az optimum létezését és meghatározását egy általánosabb keretben is vizsgálhatjuk, melyet lineáris komplementaritási feladatként fogalmazhatunk meg. Ebben a cikkben egy horizontális lineáris komplementaritási feladatra vonatkozó belsőpontos algoritmust vezetünk be, amely egy új keresési irányra alapszik. Ilyen módon egységesen kezelhetőek a sajátosabb feladatosztályoknak megfelelő belsőpontos módszerek.

Kulcsszavak: belsöpontos algoritmus, rövid lépéses módszer, horizontális lineáris komplementaritási feladat, keresési irány, Newton-módszer.

\section{Bevezetés}

Az optimalizálási feladatok felhasználhatóak különböző mérnöki problémák megoldására. Sajátosan, a lineáris komplementaritási feladat (LCP) az alábbi esetekben alkalmazható: mechanikai kölcsönhatás, dinamikus merev test modell, szerkezeti tervezés, akadálykerülés, illetve elasztohidrodinamikai kenés [5].
A lineáris optimalizálás területén nagy elörehaladást jelentett az 1984-ben Karmarkar által bevezetett projektív belsőpontos algoritmus [8]. Ez a módszer a szimplex eljárással ellentétben polinom időben határozza meg az optimális megoldást. Az LCP-re vonatkozó hagyományos belsőpontos módszerek elméletét a [9] könyv részletesen tárgyalja. A leggyakrabban a monoton LCP-t vizsgálják, melyet 
egy pozitív szemidefinit mátrix határoz meg $[6,10]$. Egy ennél általánosabb feladatkört a $P_{*}(\kappa)$ mátrixok által meghatározott feladatosztály jelenti, amelyre sikerült polinomiális belsőpontos módszert bevezetni $[1,11]$. Általános LCP-re Illés, Nagy és Terlaky adtak meg belsőpontos módszereket [7].

A belsőpontos algoritmusok esetében nagyon fontos szerepet játszik a keresési irányok meghatározása. A [4] cikkben egy új lineáris optimalizálásra vonatkozó belsőpontos módszert vezettünk be, amely egy új keresési irányra alapszik. Ez a módszer a [3] munkában lett kiterjesztve monoton LCP-re. Ebben a cikkben ezt az algoritmust horizontális lineáris komplementaritási feladatra (HLCP) általánosítjuk. A centralizálási egyenletre a $\varphi(t)=t-\sqrt{t}$ függvényt alkalmazzuk, majd a Newton-módszer segítségével kapjuk meg az új keresési irányokat. Ezt követően egy numerikus eredményt is bemutatunk.

\section{A feladat}

A horizontális lineáris komplementaritási feladat célja egy olyan $(x, s) \in \mathfrak{R}^{n} \times \mathfrak{R}^{n} \quad$ páros meghatározása, amelyre teljesülnek a következő feltételek:

$$
\begin{aligned}
& Q x+R s=b, \\
& (x, s) \geq 0, \\
& x^{T} s=0,
\end{aligned}
$$

ahol $Q, R \in \mathfrak{R}^{n \times n}, b \in \mathfrak{R}^{n}$.

Tekintsük a következö jelöléseket: $I^{+}=\left\{i: u_{i} v_{i}>0\right\}, I^{-}=\left\{i: u_{i} v_{i}<0\right\}$.

Ekkor azt mondjuk, hogy a $(Q, R)$ mátrix párosra teljesül a $P_{*}(\kappa)$ tulajdonság, ha létezik egy $\kappa \geq 0$ konstans úgy, hogy

$$
Q u+R v=0 \Rightarrow
$$

$$
(1+4 \kappa) \sum_{i \in I^{+}} u_{i} v_{i}+\sum_{i \in I^{-}} u_{i} v_{i} \geq 0,
$$

minden $u, v \in \mathfrak{R}^{n}$ esetén. Továbbá, a feladatot $P_{*}(\kappa)$-HLCP-nek hívjuk.

Feltételezzük, hogy a belső pont feltétel fennáll, azaz létezik olyan $\left(x^{0}, s^{0}\right)$ páros, amelyre:

$$
\begin{gathered}
Q x^{0}+R s^{0}=b, \\
\left(x^{0}, s^{0}\right)>0 .
\end{gathered}
$$

Az optimalitási feltétel az alábbi módon néz ki:

$$
\begin{aligned}
& Q x+R s=b, x \geq 0, \\
& x s=0, s \geq 0,
\end{aligned}
$$

ahol $x s$ az $x$ és $s$ vektorok komponensenkénti szorzata, vagyis $x s=\left[x_{1} s_{1}, x_{2} s_{2}, \ldots, x_{n} s_{n}\right]^{T}$. A centrális utat a következö rendszerrel jellemezhetjük:

$$
\begin{aligned}
& Q x+R s=b, x \geq 0, \\
& x s=\mu e, s \geq 0,
\end{aligned}
$$

ahol $e$ az egyesekből álló $n$-dimenziós vektor: $e=[1, \ldots, 1]^{T}$ és $\mu>0$. Ha a belső pont feltétel fennáll, akkor a (2) rendszernek minden rögzített $\mu>0$ esetén egyértelmü megoldása van, melyet $\mu$ - centrumnak nevezünk [13].

\section{Az új algoritmus}

A [2] cikkben bevezetett módszert fogjuk felhasználni az elmozdulásvektorok meghatározására. Ehhez tekintsük a $\varphi: \mathfrak{R}^{+} \rightarrow \mathfrak{R}^{+}$függvényt, amely a pozitív valós számok halmazán értelmezett és folytonosan differenciálható, illetve invertálható. Ekkor a centrális utat meghatározó (2) rendszer az alábbi alakban írható:

$$
Q x+R s=b, x \geq 0,
$$




$$
\varphi\left(\frac{x_{i} s_{i}}{\mu}\right)=\varphi(1), s \geq 0,
$$

bármely $i=1, \ldots, n$.

A továbbiakban a $\varphi(t)=t-\sqrt{t}$ függvénnyel foglalkozunk. Vezessük be a $v=\sqrt{\frac{x s}{\mu}}$ jelölést. Ekkor a Newtonmódszert alkalmazva a (3) rendszerre a következöt kapjuk:

$$
\begin{aligned}
& Q \Delta x+R \Delta s=0, \\
& s \Delta x+x \Delta s=\mu \frac{2 v^{2}(e-v)}{2 v-e} .
\end{aligned}
$$

Továbbá, tekintsük a $d_{x}=\frac{v \Delta x}{x}$ és $d_{s}=\frac{v \Delta s}{s}$ jelöléseket. Ebböl következik, hogy $\mu v\left(d_{x}+d_{s}\right)=s \Delta x+x \Delta s$. Ezeket felhasználva megkapjuk a skálázott rendszert:

$$
\begin{aligned}
& \bar{Q} d_{x}+\bar{R} d_{s}=0, \\
& d_{x}+d_{s}=p_{v} .
\end{aligned}
$$

ahol $\bar{Q}=Q X V^{-1}, \bar{R}=R S V^{-1}$ és

$$
p_{v}=\frac{2\left(v-v^{2}\right)}{2 v-e} \text {. Továb- }
$$

bá, $X=\operatorname{diag}(x), \quad S=\operatorname{diag}(s) \quad$ és $V=\operatorname{diag}(v)$ az $x, s$ és $v$ vektorokból alkotott diagonálmátrixok.

A centrális úttól való távolság mérésére a $\delta(x, s ; \mu)=\frac{\left\|p_{v}\right\|}{2}=\left\|\frac{v-v^{2}}{2 v-e}\right\|$ mértéket használjuk, ahol \|.\| az euklideszi normát jelöli. Az algoritmust az alábbi módon határozzuk meg:
1. algoritmus. Legyen $\varepsilon>0$ a pontossági paraméter, $0<\theta<1$ a redukciós paraméter és $0<\tau<1$ a centralitási paraméter. Feltételezzük, hogy $\left(x^{0}, s^{0}\right)$ teljesiti a belsö pont feltételt és $v^{0}=\sqrt{\frac{x^{0} s^{0}}{\mu^{0}}}>\frac{e}{2}$. Továbbá, feltételezzük, hogy $\delta\left(x^{0}, s^{0} ; \mu^{0}\right)<\tau=\frac{1}{2(1+4 \kappa)}$ és legyen $\mu^{0}=\frac{\left(x^{0}\right)^{T} s^{0}}{n}$.

begin

$$
x=x^{0} ; s=s^{0} ; \mu=\mu^{0} ;
$$

while $x^{T} s \geq \varepsilon$ do begin meghatározzuk a $(\Delta x, \Delta s)$ lépést a

(4) összefüggés alapján

$$
\begin{aligned}
& x=x+\Delta x ; s=s+\Delta s ; \\
& \mu=(1-\theta) \mu ;
\end{aligned}
$$

\section{end}

end.

\section{Numerikus eredmény}

A módszer hatékonyságát egy $\mathrm{C}++$ programozási nyelvben írt alkalmazással teszteltük. Ennek érdekében két paramétert vezettünk be, a $\sigma$ paraméter a $\mu$ paraméter csökkenésének gyorsaságát jellemzi. Továbbá, a $\rho$ állandó a lépéshossz nagyságát határozza meg a keresési irány mentén. A feladat a következöképpen néz ki [12]:

$$
Q=\left(\begin{array}{cccc}
2 & 1 & 1 & 1 \\
1 & 2 & 0 & 1 \\
1 & 0 & 1 & 2 \\
-1 & -1 & -2 & 0
\end{array}\right), b=\left(\begin{array}{c}
-8 \\
-6 \\
-4 \\
3
\end{array}\right),
$$


$R$ pedig a negyedrendü egységmátrix. A $\sigma=0.9$ és $\rho=0.95$ értékekre a következő eredményeket kaptuk: a hagyományos algoritmus 121, a $\varphi(t)=\sqrt{t}$ függvényt alkalmazó algoritmus 115 , az általunk megadott algoritmus pedig 49 iteráció alatt találta meg az optimumot.

\section{Következtetések}

Egy új HLCP-re vonatkozó belsőpontos algoritmust vezettünk be. A centrális utat meghatározó rendszer nemlineáris egyenletére egy új függvényt alkalmaztunk. Ezt követően a Newton-módszert felhasználva határoztuk meg az új keresési irányokat, majd egy numerikus eredményt is megadtunk. Ez a módszer megakadályozza azt, hogy az egyes iterációkban túl közel kerüljünk a határhoz.

\section{Köszönetnyilvánítás}

A szerzők köszönetüket fejezik ki a Collegium Talentumnak és az Erdélyi Múzeum-Egyesületnek a kutatási munkához nyújtott támogatásukért.

\section{Szakirodalmi hivatkozások}

[1] Asadi, S., Mansouri, H.: Polynomial interiorpoint algorithm for $P_{*}(\kappa)$ horizontal linear complementarity problems. Numer. Algorithms , 2013, 63(2):385-398.

[2] Darvay, Zs.: New interior point algorithms in linear programming, Advanced Modeling and Optimization, 2003, 5(1):51-92.

[3] Darvay, Zs., Papp, I-M. , Egy új primál-duál belsőpontos algoritmus lineáris komplementaritási feladatra, In Bitay Enikő (szerk.) XIX. Fiatal Müszakiak Tudományos Ülésszaka, EME Kiadó, Kolozsvár, 2014, 125-128.
[4] Darvay, Zs., Papp, I-M. , Takács, P.-R. Complexity analysis of a full-Newton step interior-point method for linear optimization. Period. Math. Hung., Accepted, 2015.

[5] Ferris, M.C.; Pang, J.S.: Engineering and economic applications of complementarity problems. Siam Rev., 1997, 39(4):669-713.

[6] Illés, T., Nagy, M.: A Mizuno-Todd-Ye type predictor-corrector algorithm for sufficient linear complementarity problems. Eur. J. Oper. Res., 2007, 181(3), 1097-1111.

[7] Illés, T., Nagy, M., Terlaky, T.: A polynomial path-following interior point algorithm for general linear complementarity problems., $J$. Global. Optim., 2010, 47(3):329-342.

[8] Karmarkar, N.K.: A new polynomial-time algorithm for linear programming, Combinatorica, 1984, 4:373-395.

[9] Kojima, M., Megiddo, N., Noma, T., Yoshise, A.: A Unified Approach to Interior Point Algorithms for Linear Complementarity Problems, Lecture Notes in Computer Science, Springer Verlag, Berlin, 1991, vol. 538.

[10] Potra, F., Interior point methods for sufficient horizontal LCP in a wide neighborhood of the central path with best known iteration complexity, SIAM J. Optim., 2014, 24(1):128.

[11] Potra, F., Sheng, R.: Predictor-corrector algorithm for solving $P_{*}(\kappa)$-matrix LCP from arbitrary positive starting points. Math. Program., 1996, 76(1):223-244.

[12] Shittkowski, K., Hock, W.: Test Examples for Nonlinear Programming Codes. Lecture Notes in Econom. and Math. Sys. Springer, Berlin, 1981.

[13] Sonnevend, Gy.: An "analytic center" for polyhedrons and new classes of global algorithms for linear (smooth, convex) programming. Lecture Notes in Control and Information Sciences, Springer Verlag, Berlin, 1986, 84:866-876. 